\title{
TWO INNOVATIONS IN MEXICAN MALVACEAE
}

\author{
Laurence J. Dorr \\ Department of Botany \\ National Museum of Natural History, MRC-166 \\ Smithsonian Institution \\ P.O. Box 37012 \\ Washington, D.C. 20013-7012, U.S.A. \\ dorr@si.edu
}

ABSTRACT

\begin{abstract}
Two innovations in the nomenclature of Mexican Malvaceae are proposed. First, Ayenia sidifolia is reestablished as the correct name for the species currently known as A. mexicana: this latter name was incorrectly proposed as a replacement name in Ayenia for Cybiostigma sidifolium. Second, the monotypic genus Veeresia endemic to Mexico is placed in synonymy under the Asian genus Reevesia, and the new combination Reevesia clarkii is proposed.
\end{abstract}

Key Words: Malvaceae, Mexico, Ayenia, Cybiostigma, Reevesia, Veeresia

\section{RESUMEN}

Se proponen dos cambios en la nomenclatura de las Malvaceae mexicanas. En primer lugar, Ayenia sidifolia se restablece como el nombre correcto para la especie actualmente conocida como A. mexicana: este último nombre fue propuesto incorrectamente como un nombre de reemplazo en Ayenia para Cybiostigma sidifolium. En segundo lugar, el género monotípico Veeresia endémico de México se pone en sinonimia bajo el género asiático Reevesia y se propone la nueva combinación Reevesia clarkii.

Palabras Claves: Malvaceae, Mexico, Ayenia, Cybiostigma, Reevesia, Veeresia

The recent publication of a checklist of the native vascular plants of Mexico (Villaseñor 2016) has prompted me to propose two changes in the nomenclature of Mexican Malvaceae. The first innovation emanates from a review of the American taxa of vascular plants described by Loefling (Dorr \& Wiersema 2010a, b) and especially several of his species of Ayenia $\mathrm{L}$. The second innovation is one that came to my attention in the early 1980s, but was set aside then out of deference to a student who undertook a project to revise the genus Reevesia Lindl. (Solheim 1991).

\section{Reestablishment of Ayenia sidifolia (Malvaceae: Byttnerioideae)}

When Turczaninow (1863) synonymized Cybiostigma Turcz. with Ayenia he proposed the replacement name A. mexicana Turcz. because he thought that A. sidifolia Loefl. ex DC. prevented him from making a new combination based on C. sidifolium Turcz. However, A. sidifolia is a nomen nudum; an unintentional orthographic corruption of the earlier A. sidiformis Loefl., nom. rej. There was therefore no impediment to making a combination based on C. sidifolium and the correct name for this species in the genus Ayenia as a consequence is A. sidifolia (Turcz.) Hemsl.

Standley (1923) treated Ayenia mexicana as a doubtful species, but it is not clear why he did this. Cristóbal (1960, 1961), who revised the genus Ayenia, adopted A. mexicana and her choice, albeit incorrect, has been followed in the few floras that treat this species (Fryxell 2001; Machuca-Machuca 2015) as well as in the checklist of the vascular flora of Mexico (Villaseñor 2016).

Ayenia sidifolia (Turcz.) Hemsl., Biol. Cent.-Amer., Bot. 1(2):135. 1879 (as "sidafolia"), non Ayenia sidiformis Loefl., Iter. Hispan. 257. 1758 (as "Sidaeformis"), nom. rej. Cybiostigma sidifolium Turcz., Bull. Soc. Imp. Naturalistes Moscou 25(3):155. 1852. Ayenia mexicana Turcz., Bull. Soc. Imp. Naturalistes Moscou 36(2):569. 1863, nom. superfl. Type: Mexico. Oaxaca: savannah near the Pacific, 3000 ft, 1840 (fl), H. Galeotti 326 (LEстотуPE, as "tipo" designated by Cristóbal 1960: G [G00358304 as image!]; ISOLECTOTYPES: BR [BR0000005423101 as image!], K [K000543778]!, K [K000543779]!, KW [KW001000156 as image!], P [P02286136 as image!]) 
Ayenia nelsonii Rose, Contr. U.S. Natl. Herb. 8(4):321. 1905 (as "nelsoni"). Type: Mexico. Chiapas: roadside between San Ricardo and Ocozantla, 1600-3300 ft, 18 Aug 1895 (fl), E.W. Nelson 2982 (ноLотуре: US [US000102169]!).

Distribution.-This species occurs in central, western, and southern Mexico and adjacent Guatemala; 400$1850 \mathrm{~m}$. Its precise range needs clarification; in particular the state records from the Yucatán Peninsula cited by Villaseñor (2016) are suspect and need to be verified.

Representative specimens examined: MEXICO. Chiapas: Mpio. Osumacinta: steep canon between Soyalo and La Bombana on road to Chicoasen, 10 km WNW of Soyalo, 7 Aug 1981 (fl), D.E. Breedlove 51986 (US); Hacienda Monserrate, Sep 1923 (fl), C.A. Purpus 9228 (MO, US). Guerrero: Mpio. Apango: Tlamamacan, 1754'48”, 099³1'50”W, 1 Sep 2005 (fl), J. Amith et al. 669 (US); Mpio. Tepecoacuilco de Trujano: Cerca de Iguala, en Valerio Trujano, 30 Aug 1960 (fl), C. Cristóbal 601 (MO); Coyuco, Jaripo, 5 Nov 1934 (fr), G.B. Hinton 6928 (K). Near Iguala, 3500 ft, 11 Oct 1900 (fl, fr), C.G. Pringle 9254 (MO, US); bluffs of Balsas River, 2000 ft, 27 Sep 1905 (fl), C.G. Pringle 10070 (K, MO, P [P06697391 as image], US(2) ). México: District of Temascaltepec, Chorrera, 15 Oct 1932 (fr), G.B. Hinton 2193 (ASU [ASU0049915 as image], DES [DES00005210 as image], GBH [as image], US).

\section{A new combination in Reevesia (Malvaceae: Helicteroideae)}

When the monotypic American genus Veeresia Monach. \& Moldenke was described, its authors (Monachino \& Moldenke in Monachino 1940) recognized that it was closely related to the Asian genus Reevesia. They thought their new genus differed from Reevesia principally in the presence of staminodes. Solheim $(1987,1991)$ synonymized the two genera because this principal differentiating character is not supported; both genera have minute tooth-like staminodes at the summit of the anther column. Subsequently, Terada \& Suzuki (1998), Pire \& Cristóbal (2001), Bayer (2003), and Tang et al. (2007) have considered these two genera to be synonymous. The failure to formally make this synonymy explicit by transferring Veeresia clarkii Monach. \& Moldenke to Reevesia muddles discussions about relationships between the floras of eastern Asia and North America (see e.g., Cristóbal 1987; Manchester et al. 2009) and about the phylogenetic relationships of fossil woods (Terada \& Suzuki 1998; Kvaček 2006; Jeong et al. 2009; Manchester et al. 2006; Lim et al. 2010; Li et al. 2015).

Reevesia clarkii (Monach. \& Moldenke) Solheim ex Dorr, comb. nov. (Fig. 1). Veeresia clarkii Monach. \& Moldenke, Bull. Torrey Bot. Club 67:621. 1940 (as "Clarkii"). Type: Mexico. HidalGo: mountainsides N of Chapahuacan, $8000 \mathrm{ft}, 2 \mathrm{Jul} 1935$ (fl), O.M. Clark 7401 (ноLотүPE: NY [NY00222433]!; ;SOTYPES: MO [MO-194628]!, NY [NY00023376]!).

Distribution.—Endemic to Mexico where it is found in the mountains of Hidalgo and Querétaro; 800-1300 m. A Guatemalan record (Parker 2008, as "Veeresia clarkii") is not vouchered and cannot be verified. Several Nicaraguan records (Cristóbal 2001, as "Veeresia clarkii") probably represent a distinct species of Reevesia (Solheim, 1991).

Common names.-Aquiche, conote [sic], jonote, and jonote amargoso.

Representative specimens examined: MEXICO. Hidalgo. Mpio. Chapulhuacan: N of Chapahuacan, 2 Jul 1935, O.M. Clark 2212 (UNM [UNM00035 as image]); $2 \mathrm{~km} \mathrm{~N}$ of Chapulhuacan along trail to transmission tower W of road from Chapulhuacan to Hacienda de Cahuazas, ca. $1.5 \mathrm{~km}$ E of Hwy 85, ca. $17 \mathrm{~km}$ SW of Tamazunchale, S.L.P., $21^{\circ} 10^{\prime} \mathrm{N}, 098^{\circ} 53^{\prime} \mathrm{W}, 22 \mathrm{Jun}$ 1986, G.E. Schatz 1200 (MO); 2 km N of Chapulhuacan around trail to transmission tower W of road from Chapulhuacan to Hacienda de Cahuazas, ca. $1.5 \mathrm{~km}$ E of Mexico Highway 85 , ca. $14 \mathrm{~km} \mathrm{SW}$ of Tamazunchale, S.L.P., $21^{\circ} 10^{\prime} \mathrm{N}, 098^{\circ} 53^{\prime} \mathrm{W}, 7 \mathrm{Jul} 1984$ (fl), S.L. Solheim 1765 (BR [BR0000005422852 as image], K, MO, NY, P [P02286062 as image], US); $2 \mathrm{~km} \mathrm{~N}$ of Chapulhuacan, near transmission tower W of road to Cahuazas, ca. $1.5 \mathrm{~km} \mathrm{E} \mathrm{of} \mathrm{Mex.} \mathrm{Hwy} 85,14 \mathrm{~km}$ SW of Tamazunchale, $21^{\circ} 10^{\prime} \mathrm{N}, 098^{\circ} 53^{\prime} \mathrm{W}, 25$ Oct 1986 (fr), S.L. Solheim 2067 (MO, NY(2), US(2)). Querétaro: Mpio. Jalpan: 3-4 km al Norte de La Parada, 28 Jun 1991 (fl), B. Servín 1144 (MO, US); 5-6 km al Norte de La Parada, 19 Sep 1991 (fr), B. Servín 1337 (US); Mpio. Landa: Al W de El Humo, 23 Jul 1991 (fl), E. Carranza 3295 (US); 2 km al Norte de Neblinas, 29 Sep 1988 (fr), H. Rubio 183 (US); Rancho Nuevo, 2 km al Sureste de San Onofre, 7 Jul 1989 (fl), H. Rubio 875 (US); 1 km al Sureste de San Onofre, 17 Jun 1991 (fl), H. Rubio 2435 (US); 1.5 km al Noroeste de San Onofre, 30 Jun 1991 (fl), H. Rubio 2444 (US); 1 km al Noroeste de San Onofre, 3 Aug 1991 (im fr), H. Rubio 2522 (US); 1 km al Poniente de El Humo, 19 Aug 1991 (fr), H. Rubio 2557 (US); 10 km al NE de Agua Zarga, sobre el camino a Neblinas, 23 Jun 1988 (fl), J. Rzedowski 46826 (MO, US). 


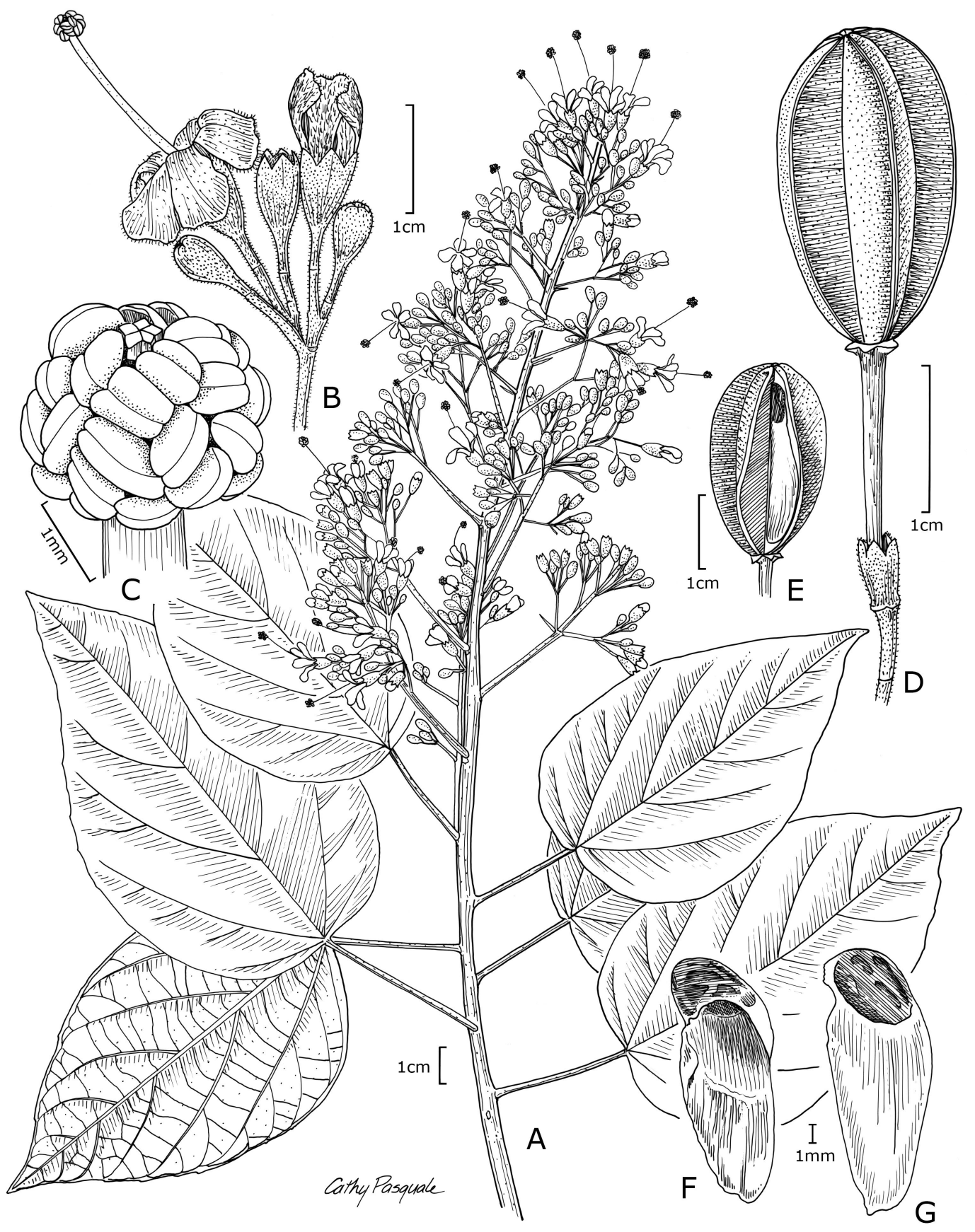

FIG. 1. Reevesia clarkii. A. Habit. B. Flower at anthesis and floral buds. C. Anthers clustered at apex of staminal column; 5-lobed stigma visible in center. D. Fruit. E. Fruit with one locule open to show the apical attachment of a seed. F, G. Pair of seeds showing development of the wings. (A, C, Servín 1144; B, Rubio 2444; D-G, Solheim 2067. Illustration by C. Pasquale). 


\section{ACKNOWLEDGMENTS}

Erika Pagaza-Calderón (HJBC) and an anonymous reviewer provided helpful comments on the manuscript.

\section{REFERENCES}

BAYER, C. 2003. Malvaceae. In: K. Kubitzki \& C. Bayer, eds. The families and genera of vascular plants. Volume 5. SpringerVerlag, Berlin, Germany. Pp. 225-311.

CRIStóbal, C.L. 1960. Revisión del género Ayenia (Sterculiaceae). Opera Lilloana 4:1-230.

CRIStóbal, C.L. 1961 [1962]. Nueva contribución al estudio del género Ayenia (Sterculiaceae). Anales Inst. Biol. Univ. Nac. Mexico 32:191-200.

CRIStóbal, C.L. 1987. Un Helicteres nuevo de México, nexo entre las especies Asiaticas y Americanas. Bonplandia 6:71-81. Cristóbal, C.L. 2001. Sterculiaceae. In: W.D. Stevens, C. Ulloa Ulloa, A. Pool, \& O.M. Montiel, eds. Flora de Nicaragua. Tomo 3. Monogr. Syst. Bot. Missouri Bot. Gard. 85:2428-2437.

DoRR, L.J. \& J.H. WIERSEMA. 2010a. Names of American vascular plants published in Loefling's Iter Hispanicum (1758) and its German translation (1766). Taxon 59:1245-1262.

DoRR, L.J. \& J.H. WieRSEMA. 2010b. (1947-1958) Proposals to reject twelve names emanating from Loefling's Iter Hispanicum (1758), Ayenia sidiformis (Malvaceae), Cofer (Symplocaceae), Cruzeta and C. hispanica (Amaranthaceae), Edechia inermis and E. spinosa (Rubiaceae), Justicia putata (Acanthaceae), Menais and M. topiaria (? Boraginaceae), Muco (Capparaceae), Samyda parviflora (Salicaceae), and Spermacoce suffruticosa (Rubiaceae). Taxon 59:1280-1282.

FryxelL, P.A. 2001. Sterculiaceae. In: R. McVaugh, ed. Flora Novo-Galiciana. Volume 3. The University of Michigan Herbarium, Ann Arbor, U.S.A. Pp. 110-147.

Jeong, E.K., K. Kyungsik, M. SuzukI, \& J.W. KIm. 2009. Fossil woods from the Lower Coal-bearing Formation of the Janggi Group (Early Miocene) in the Pohang Basin, Korea. Rev. Palaeobot. Palynol. 153:124-138. doi:10.1016/j. revpalbo.2008.07.006

KvačEK, Z. 2006. Fossil fruits of Reevesia (Malvaceae, subfam. Helicteroideae) and associated plant organs (seeds, foliage) from the Lower Miocene of North Bohemia (Czech Republic). Neues Jahrb. Geol. Paläontol., Monatsh. 2006 (7):431-448.

LI, Y.-J., A.A. Oskolskı, F.M.B. Jacques, \& Z.-K. Zhou. 2015. New middle Miocene fossil wood of Wataria (Malvaceae) from Southwest China. IAWA J. 36:345-357.

LIM, J.-D., E.-K. JeONG, K. KIM, M. SUZUKI, I.S. PAIK, \& H.-M. KIM. 2010. Micoene woods of the Janggi Basin in Korea: Implications for paleofloral changes. Geosciences J. 14:11-22. doi:10.1007/s12303-010-0002-8

MachucA-MachuCA, K. 2015. Sterculiaceae. In: R. Medina Lemos, ed. Flora del valle de Tehuacán-Cuicatlán. Volume 128. Instituto de Biología, Universdidad Nacional Autónoma de México, México, D.F. Pp. 1-43.

Manchester, S.R., Z.-D. Chen, A.-M. Lu, \& K. Uemura. 2009. Eastern Asian seed plant endemic genera and their paleogeographic history through the northern hemisphere. J. Syst. Evol. 47:1-42. doi:10.1111/j.1759-6831.2009.00001.x

MANCHESTER, S.R., Z. CHEN, \& Z. ZHou. 2006. Wood anatomy of Craigia (Malvales) from southeastern Yunnan, China. IAWA J. 27:29-136. doi:10.1163/22941932-90000142

MonACHINO, J. 1940. A new genus and species of Sterculiaceae. Bull. Torrey Bot. Club 67:621-622. doi:10.2307/2481584

Parker, T. 2008. Trees of Guatemala. The Tree Press, Austin, Texas, U.S.A. Pp. i-vi, 1-1033.

PIRE, S.M. \& C.L. CRISTóBAL. 2001. El polen de Helicteres (Sterculiaceae) y su comparación con géneros vecinos. Bonplandia 11:207-230.

SolHeIM, S.L. 1987. Reevesia (Sterculiaceae, Helictereae): Systematics and biogeography of an Asian-Eastern American disjunction. Amer. J. Bot. 74:754. [Abstract].

Solheim, S.L. 1991. Reevesia and Ungeria (Sterculiaceae): A taxonomic and biogeographic study. Ph.D. Dissertation, University of Wisconsin, Madison, Wisconsin, U.S.A. Pp. i-xv, 1-383.

Standley, P.C. 1923. Trees and shrubs of Mexico. Contr. U.S. Natl. Herb. 23(3):i-iii, 517-848, v-xxviii.

TANG, Y., M.G. Gilbert, \& L.J. Dorr. 2007. Sterculiaceae. In: X. Wu, P.H. Raven \& D. Hong, eds., Flora of China. Volume 12. Science Press, Beijing/Missouri Botanical Garden Press, St. Louis, Missouri, U.S.A. Pp. 302-330.

TeRAdA, K. \& M. SuzUKI. 1998. Revision of the so-called'Reevesia' fossil woods from the Tertiary in Japan-a proposal of the new genus Wataria (Sterculiaceae). Rev. Palaeobot. Palynol. 103:235-251.

TurCZANINOW, N. 1863. Animadversiones ad catalogum primum et secundum herbaria universitatis charkoviensis. Bull. Soc. Imp. Naturalistes Moscou 36(2):545-615.

VillaseñoR, J.L. 2016. Checklist of the native vascular plants of Mexico. Revista Mex. Biol. 87:559-902. doi:10.1016/j. rmb.2016.06.017 